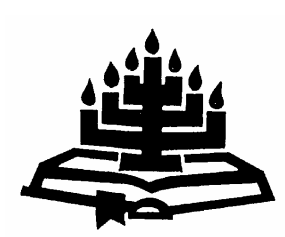

\title{
'n Pastoraal-narratiewe metode om lewenshanteringsvaardighede by kankerpasiënte te identifiseer
}

\author{
J. Steyn \& J.-A. van den Berg \\ Praktiese Teologie \\ Universiteit van die Vrystaat \\ BLOEMFONTEIN
}

E-pos: steynj.hum@mail.uovs.ac.za

vdbergja.hum@mail.uovs.ac.za

\begin{abstract}
Identifying life-coping skills for cancer patients by means of a pastoral narrative method

A cluster of life-coping skills are explained in the context of case studies involving cancer patients. Patients' alternative life stories may be compared to fresh springs of water, gushing forth to yield new purposeful lives. The arguments in this article are intended to direct pastoral therapists and caregivers towards meaningful interaction with cancer patients, assisting the latter to accept the diagnosis on the basis of understanding and knowledge of what has happened to them. Knowledge implies externalisation, the use of metaphors, acceptance and hope. The coping mechanism of meaningful relationships may link past and present relationships so that the patient's support base and ability to cope and grow may be strengthened. A deepening of faith and a service orientation may function as coping skills as the cancer patient attempts to satisfy the need to feel cared for by means of caring for others. New hobbies may emerge and the patient may, especially in groups, learn to redirect creative energy. A renewed worth in Christ deepens the coping base by way of a link with the great narrative of the Scriptures.
\end{abstract}


Opsomming

'n Pastoraal-narratiewe metode om lewenshanteringsvaardighede by kankerpasiënte te identifiseer

Lewenshanteringsvaardighede word in hierdie artikel saamgegroepeer en verduidelik aan die hand van verhaalstudies van kankerpasiënte. Alternatiewe lewensverhale van pasiënte kan soos fonteine ontspring wanneer 'n pasiënt sy verhaal vertel en daar, volgens die persoonlike ontwikkeling in die verhaal, 'n nuwe doelgerigte lewe ontstaan. Die argumente in hierdie artikel het ten doel om pastorale terapeute en versorgers te ondersteun in die betekenisvolle begeleiding van pasiënte om deur die narratief, die diagnose te aanvaar op grond van die begrip en kennis van wat besig is om plaas te vind. Kennis impliseer eksternalisering, die gebruik van metafore, aanvaarding en hoop. Die hanteringsvaardigheid van betekenisvolle verhoudings kan verhoudings van die verlede en hede aanmekaar knoop, sodat die pasiënt se ondersteuningsbasis en potensiële vermoë om te groei, versterk word. Geloofsverdieping en diensbaarheid mag funksioneer as hanteringsvaardighede wanneer die kankerpasiënt sy/haar eie behoefte aan omgee omskakel in omgee vir ander. Nuwe stokperdjies mag na vore tree en die pasiënt mag, veral in groepe, leer om kreatiewe energie nuut aan te wend. ' $n$ Vernuwende waarde in Christus verdiep die basis van hantering en verbind ook die narratief met die groot narratief van die Skrif.

\section{Inleiding}

Brian (7-jaar) wat gediagnoseer is met 'n maligne (kwaadaardige) breintumor, word in die hospitaal agtergelaat omdat sy ma na haar werk moes terugkeer. Sy troos hom met die woorde: "Onthou, Jesus is altyd by jou." Gefrustreerd verwoord hy sy vrees: "Maar ek wil Jesus met vleis om hê!"

Selfs vir 'n volwasse kankerlyer is hierdie "afwesigheid" van 'n tasbare Verlosser 'n strydvraag wat bly maal: "Waar is God dan?" Louw (1982:6) verwys hierna as die "leer oor die teenwoordigheid van die lewende God" te midde van trauma en die besef van die mens se verganklikheid.

Yancey (2001:235-237) beantwoord hierdie eeue oue vraagstuk van "Waar is God dan?", vanuit die perspektief van Nuwe-Testamentiese skrywers. Volgens Romeine 8, tree die Heilige Gees vir ons in met "onuitspreeklike versugtinge". Die Heilige Gees verwoord dus die mens se innerlike pyn en versugtinge deur die vleesgeworde Woord, 
Jesus Christus, waar Hy by God vir die mens intree. Tog, stel Yancey (2001:236):

The Holy Spirit is just that - a spirit: invisible, quick as the wind, inaccessible to human touch. And heaven lies off in the future somewhere. What about right now? What can reassure us physically and visibly of God's love here on earth?

Yancey vervolg verder dat 'n tweede antwoord bestaan in 'n "misterieuse" (die "onsigbare" hoof) frase wat dertig keer herhaal word in die Pauliniese literatuur, naamlik die "liggaam van Christus". In 2 Korintiërs 1:3-5 word dié uitgangspunt so bevestig:

Geseënd is die God en Vader van onse Here Jesus Christus, die Vader van ontferminge en die God van alle vertroosting, wat ons troos in al ons verdrukking, sodat ons die wat in allerhande verdrukking is, kan troos deur die vertroosting waarmee ons self deur God getroos word.

Christus se besluit om as die "onsigbare" hoof van die menigvuldige lede te funksioneer, affekteer ons siening op lyding en word saamgevat in die bogenoemde gedeelte uit 2 Korintiërs 1:3-5. Behalwe dat die mensdom veel nader na mekaar toe beweeg as gevolg van pyn en lyding, bring dit ook vertroosting en nuwe kreatiwiteit na vore waarin daar saam besin kan word oor die hóé (hantering) van pyn en lyding. Om wetenskaplik te besin oor die hanteringsvaardighede van pyn en lyding, vra na 'n navorsingsmetode soos Deelnemendeaksienavorsing (sien omskrywing onder metode).

\section{Motivering}

Deur gebruikmaking van dekonstruksie, eksternalisering en metafore van die verhale van kankerpasiënte word die pasiënt in staat gestel om lewenshanteringsvaardighede te identifiseer en 'n kreatiewe alternatiewe storie te skryf. Dié artikel het ten doel om uit kreatiewe alternatiewe verhale die lewenshanteringsvaardighede uit te sif en saam te voeg in 'n geheel sodat identifisering deur pastorale versorgers en hospitaalbedienaars vergemaklik kan word. Die pasiënt kan dié vaardighede in werking stel om te beweeg vanuit totale wanhoop en meesleuring in 'n maalkolk-situasie, na kalmer waters "wat nooit teleurstel nie" (Jes. 58:11). 


\section{Begripsomskrywing en metode}

'n Lewenshanteringsvaardigheid (coping skill of natural growth enabler) (Clinebell, 1984:451) dui op 'n metode of tegniek of gebeurlikheid waarna teruggegaan kan word (dikwels vanuit die sekondêre storielyn) om die geïnternaliseerde fisiese, emosionele of spirituele pyn wat tydens die dominante narratief mag voorkom, te eksternaliseer (White \& Epston, 1990:38). Die persoon word dus in staat gestel om die pyn en lyding te hanteer op grond van vorige ervaring. Wylie stel dit soos volg: "We don't need to teach people anything new, just help them reach stuff that's already there" (Wylie, 1994:48).

Vanuit bogenoemde omskrywing kan die afleiding gemaak word dat die dominante storielyn, wat dikwels probleemdeurdrenk is (White \& Epston, 1990:38) van 'n sekondêre storielyn voorsien kan word wat unieke uitkomstes vorendag kan bring. Hierdie unieke uitkomstes kan lei tot die ontwikkeling van lewenshanteringsvaardighede.

Lewenshanteringsvaardighede word gegroepeer in die artikel en aan die hand van grepe uit verhalestudies van kankerpasiënte verduidelik. Daar kan nie gewag gemaak word van 'n somtotaal van lewenshanteringsvaardighede nie, omdat elke verhaal uniek is. Powell (2004:358) verwys byvoorbeeld daarna dat elke persoon 'n coping style het, wat grootliks aan voorkeure en of persoonlikheid gekoppel kan word. Slegs enkele vaardighede soos uit narratiewe gedekonstrueer, word geïdentifiseer en in hierdie artikel bespreek.

Elke verhalestudie kan nie in diepte ontleed word nie, maar verskillende fragmente word gebruik ter illustrasie van twee verhale. Die eerste verhaal verwys na dié van 'n maligne karsinoom en die ander verhaal verwys na die doel van elke mens se lewe, soos ingebed in die verbond (ooreenkoms) met God (Ps. 139).

Metafore word deurgaans gebruik soos die pasiënte hul ervarings daarmee verwoord. Die metafoor bied 'n verstaansgreep in elke mens se verhaal en is volgens Van den Berg (1998:203) in staat om "nie net menslike ervaring te beskryf nie, maar ook bomenslike, religieuse ervaring". Willie beskryf byvoorbeeld sy verwarring na 'n trauma met die woorde: "Ek was in 'n maalkolk". Dié metafoor in samehang met die metafore in Jesaja 58:11, sal gebruik word om pasiënte se lewenshanteringsvaardighede beeldend te vergestalt.

Die teorie van 'n Pastoraal-narratief (Steyn, 2004:16), 'n Pneumatologiese model (Van Jaarsveld, 2001:83) en Deelnemendeaksienavorsing (Strydom, 2002:419), word in die artikel as basis 
gebruik om probleemvrae na te vors. Die narratief verwys na die verhaal of storie (geskiedenis) van 'n persoon.

'n Pastoraal-narratiewe benadering gee aan pastorale versorging sy kernfunksie (inner core) (Browning,1991:193). Die pastorale terapeut sien in die Pastoraal-narratiewe teorie die mens se storie ingedoop in God se groot narratief. Die klem val op die betekenis van die voorsetsel "in" (ep-ee of eij). Ons word ingedoop, in of tot die Drie-eenheid (Pretorius, 2003:166). Ingedoop verwys na die unieke uitkoms van Christus se sendingopdrag, soos verwoord in Matteus 28:19 en word ook in die Pauliniese geskrifte en Johannes se woorde sterk beklemtoon, byvoorbeeld: "Hieraan weet ons dat ons in Hom bly en Hy in ons" (1 Joh. 4:13).

Die narratief is nie slegs ' $n$ metode nie maar 'n paradigma (Lester, 1995:39-42). Elke mens se storie is integraal deel van God se narratief. Die mens se verhaal kan nie verstaan word sonder om te kyk na die volle prentjie waarin die mens saam met God stap nie (Steyn, 2004:3).

Die uitgangspunte van die Pneumatologiese model gee aan die pastorale versorger die krag en wysheid (Jes. 11:2b) om die Heilige Gees, as bondgenoot in die pastorale situasie te vertrou. Die kankerpasiënt wat vasgevang is in die maalkolk van vrae, pyn, ontkenning en opstand kan aan die hand van 'n metafoor soos die maalkolk, gelei word tot hantering van die situasie. Ook 'n moontlike opstand en losskeuring van die koinonia met God, kan deur terugleiding na kalmer waters van die vredesverbond, deur Christus gebied word (Janse van Rensburg, 1996:154).

Deelnemendeaksienavorsing (Strydom, 2002:419-423) betoog dat navorsing 'n bemagtigende deelname van mede-navorsers moet wees. Die kankerpasiënte as individue vorm bewustelik deel van die aksie om te soek na lewenshanteringsvaardighede in elkeen se eie narratief. Dit pas in by die narratiewe teorie, waar onder andere gewerk word met 'n nie-wetende benadering (Anderson \& Goolishian, 1992:29). Saam word gekyk na vaardighede waarin die kankerpasiënt sy/haar maalkolk-situasie, wat 'n dominante storie geword het, herskryf in 'n alternatiewe storie, waaruit 'n nuwe lewenstroom kan ontspring.

Dié metode van navorsing sluit aan by die Christian Life Review, soos gebruik deur Lefavi en Wessels (2003). Hierin is aangetoon dat die Christelike lewensoorsig of -verhaal 'n positiewe invloed op lewensbegeleidings en -hanteringsvaardighede van terminale 
pasiënte uitoefen. Pasiënte wat nie maklik hulle verhaal kan verwoord nie, word deur middel van gestruktureerde vrae gelei om tot die besef te kom van "wat is my waarde in Christus". Byvoorbeeld, op 'n vraag aan Ria of sy bewus was daarvan dat Jesus by haar was tydens haar kind se siekte, was haar antwoord:

Ek het die heel aand langs hom gelê en bid dat die Here ons in genade sal aansien. In die nag het ek meteens wakker geword van 'n helder lig wat in die kamer skyn. Ek het opgestaan om te kyk watter motor hou nou so naby aan die huis stil. Toe ek op my twee voete staan het 'n warm gevoel my hele lyf deurspoel en ek het geweet, Jesus is by ons, Hy is die Lig. My kind gaan gesond word.

Die volgende probleemvrae sal in die artikel nagevors word:

- Watter lewenshanteringsvaardighede kan deur die pasiënt geïdentifiseer word om vanaf die maalkolk-situasie na die "fontein wat nooit teleurstel nie" te ontwikkel?

- Op watter wyse kan dié vaardighede aangewend word sodat 'n nuwe, kreatiewe en alternatiewe storie ontwikkel kan word?

- Hoe kan die dominante (maalkolk-)narratief van die pasiënt teruggebind word aan God se groot narratief?

Aan pasiënte wat moeilik hul verhaal kon formuleer, is vrae gevra en dan dekonstruerend te werk gegaan, sodat hy/sy self die hanteringsvaardighede na vore kon bring. Ander pasiënte het spontaan hul verhale vertel en dan is daar deelnemend op dieselfde wyse vaardighede uitgewys. Hierdie aanpak sluit aan by die Christian Life Review en die Deelnemendeaksienavorsing waarna verwys is.

Die volgende raamwerk van lewenshanteringsvaardighede wat onderskei is, sal saamgegroepeer word (clusters vorm). Die groepering sal verduidelik word in die bespreking wat volg.

Onder elke hoofopskrif sal verdere begrippe kortliks omskryf word, daarna sal die identifisering van die groepering van vaardighede vanuit die verhalestudies aangedui word en laastens sal 'n samevatting gegee word om aan te dui hoe daar onder dié tema tot beantwoording van probleemvrae gekom is.

Die pasiënte word geïdentifiseer deur slegs name te gebruik. Die verhalestudies is byeengebring in 'n joernaal (Steyn, 2001-2005). 


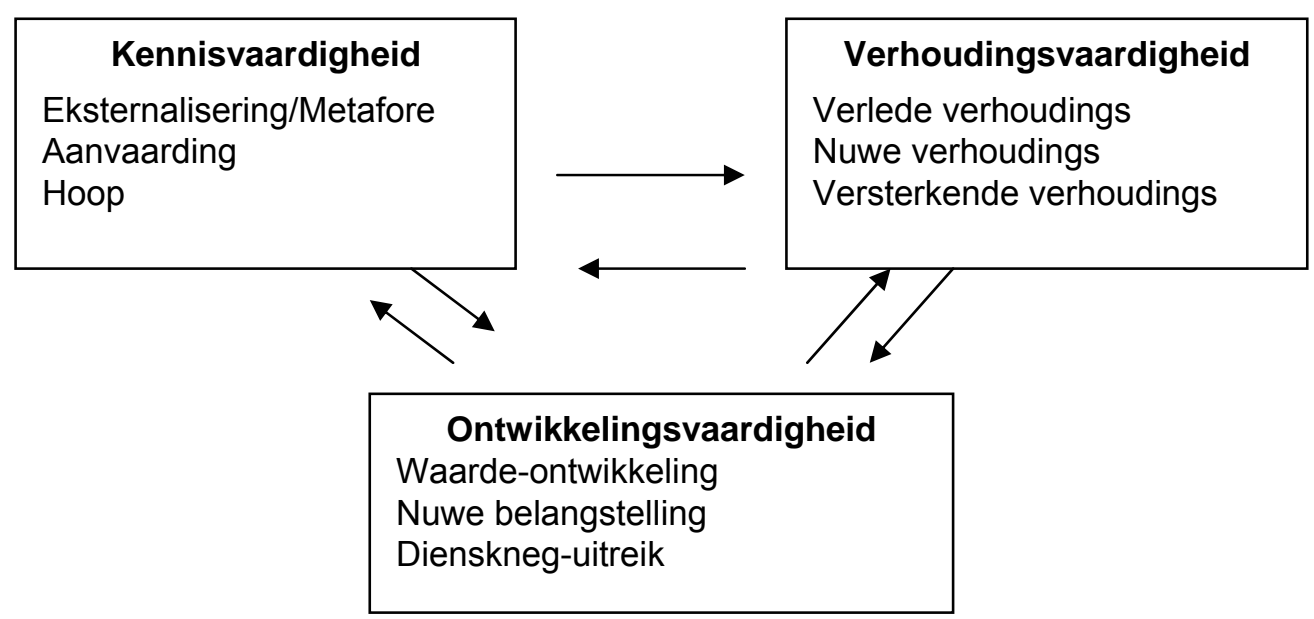

\section{Kennisvaardigheid}

Die Here sal jou gedurigdeur lei en jou siel versadig in dor plekke en jou gebeente sterk maak (Jes. 58:11).

Clinebell (1984:451) verwys daarna dat Lewenshanteringsvaardighede (natural growth enablers) nie natuurlik ontwikkel vanuit 'n maalkolk-situasie nie. Begeleiding en terapie is volgens hom noodsaaklik om vaardighede wat hoop en ontwikkeling sal optimeer, te identifiseer. Pastorale versorging begin met 'n posisie-inname van luister na die gespreksgenoot en eers wanneer 'n pasiënt sy verhaal of probleem onder woorde bring, begin die verwerking daarvan.

Ek was in 'n maalkolk. Die maalkolk was so erg dat ek selfs nie kon onthou om my skoene vas te maak nie. Daarom dat ek jou nie kon onthou of waar ek jou adres gebêre het nie. Nou eers dat ek daaruit is, het ek onthou van jou en kon ek jou adres opspoor.

Dié maalkolk-metafoor van Willie beskryf die verwarring, uitblokkering deur vrees, hartseer, oorlading van alledaagse geheuesisteme en emosionele wanhoop na die dood van sy seun aan 'n maligne karsinoom. Geheuesisteme word volgens White (2004:48) tydelik uitgeblokkeer wanneer enige persoon in 'n traumasituasie verkeer. Die metafoor bied die moontlikheid tot uitbou, verdieping en verstaan van die siekte en omstandighede wat in 'n terapeutiese situasie uitgepak kan word. Die metafoor bied verder ook 'n metode om twee wêrelde, dié van terapeut en pasiënt, te laat ineenvloei, diepte te gee en ook 'n deling van grondgebied te verseker. 
Nadat 'n persoon gediagnoseer is met kanker, gaan hy/sy deur 'n maalkolk van ontkenning-opstand-rasionalisasie-ooreenkomsmaking (vgl. ook Kübler-Ross, 1975 se fases). Enige woord of onskuldige opmerking van 'n buitestaander kan die situasie tot die spits dryf, wat 'n pasiënt tot 'n woede-uitbarsting of totale onttrekking kan stuur. Marius, 'n motorwerktuigkundige, het byvoorbeeld homself onttrek van kennisbronne oor sy limfkanker en wou tot die dag van sy dood geen inligting oor sy siekte hoor nie. Sy woorde was:

Die dokter het gesê ek het limfkanker en as ek wil weet wat dit is, moet ek op 'n rekenaar gaan kyk. Die suster van KANSA wou my vertel wat die siekte beteken, maar ek het haar weggejaag. Ek wil dit nie hoor nie!

Hoewel Marius nie op 'n kennis-konseptualiseringsvlak verwerking van sy siekte wou bewerkstellig nie, het die metafoor van die elektroniese motortjies wat hy saam met sy sewejarige seun gebou het, vir hom verwerking van sy siekte gegee. Hy kon 'n parallel trek tussen die motortjie waarvan verskeie onderdele vervang moet word en sy eie "liggaamsonderdele" wat met die verloop van die siekte besig was om in te gee.

Vir Marius het die metafoor van elektroniese motortjies eksternalisering bewerkstellig in die maalkolk van onsekerheid. Die metafoor was ook die brug na aanvaarding en hoop.

Op 'n vraag aan Annatjie: "Hoe het die mediese dokter die nuus dat jy kanker het aan jou bekend gemaak?", was haar antwoord:

Hy het vir my gesê: "Jy sal seker nou van my wil weet hoeveel tyd jy het voor jy doodgaan?" Ek is vandag, na vyf jaar, nog skaam dat ek hom so ingevlieg het. Ek het vir hom gevra of hy dan dink hy is God om dit te weet! Ek wou inligting oor my siekte hê en nie voorspellings oor my sterfdag nie!

Albei die situasies verduidelik die krisis waarin 'n persoon hom/haarself bevind na so 'n diagnose. Twee soorte persoonlikhede kom hieruit na vore, dié mens wat nie belangstel om inligting oor die soort kanker te bekom nie, en die ander persoon wat graag inligting wil bekom, omdat dit moontlik 'n beter verstaan, verwerking en hoop na vore kan bring.

Die eerste groepering van vaardighede, verwys daarna dat inligting, eksternalisering en metafore help met die aanvaarding van die siekte en ook kan lei tot hoop. 
Op 'n vraag aan Bettie: "Hoe kan 'n mens hoop behou in sulke omstandighede?", was haar reaksie:

Jy moet jou instel op realistiese hoop. Dit help nie jy bly hoop dat jy gesond word, maar jy weet die siekte het al te ver gevorder daarvoor nie - dan is jou hoop nie meer gegrond op die realiteit nie en kan dit nie meer hoop wees nie.

Die verstaan van die inligting rondom die siekte, lei dus nie net tot die verwerking van die krisis nie, maar ook tot die ontwikkeling van realistiese hoop.

Tydens die maalkolk-periode is dit van belang om die probleem te eksternaliseer. Slegs dán word afstand ervaar en kan inligting oor die siekte beter verwerk word. Botha (2003:15) stel dat 'n krisis "nie die klip (probleem) is wat jou tref nie, dit is die prentjie in jou kop wat jy van die krisis vorm, dit is die probleem". Müller sluit tydens 'n werkswinkel hierby aan en sê: "die probleem is die probleem", die pasiënt is dus nie die probleem nie (Müller \& Human, 2004).

Net voordat Faan vir 'n operasie moes gaan, sê hy:

Ek is so rondgeslinger van die een kant na die ander kant omdat ek aanhou maal het in my kop oor die operasie wat voorlê. Eers toe die Here my in die middernagtelike ure regop laat sit met die vraag: 'Faan, ken jy Psalm 23?' en ek antwoord 'Ja Here,' en Hy weer vir my vra: 'Faan, ken jy regtig Psalm 23?' Dis toe dat ek besef het, ek het vergeet: 'Die Here is my Herder'. Hy is altyd by my, selfs nou en hier wat ek so rondgejaag word soos ' $n$ verlore skaap in 'n bos! Eers toe het ek besef, dis die siekte wat van my 'n weerlose skaap maak. Selfs nie die siekte kan my uit die Here se arms wegruk nie.

Dit is kenmerkend dat pasiënte in die maalkolk-periode, en soms daarna, verwys na 'n metafoor om die situasie te beskryf.

Metafore soos "ek val voortdurend van lere af", "ek hardloop oor en oor teen myself vas", "dis 'n doolhof waardeur ek moes worstel", "dit voel of my kop oorlaai is en kortsluitings voortdurend daarin blits" en "die gewone wipplank van die lewe het ontaard in 'n roller coaster het die volgende uitbeelding na vore gebring:

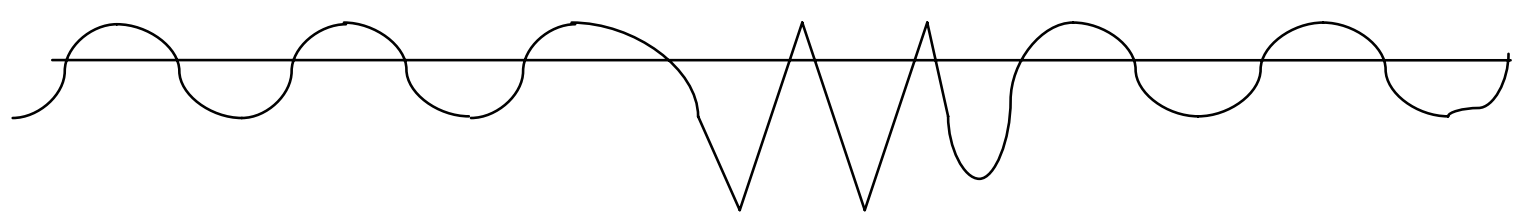


Die egalige vloei van 'n lewenstroom is skielik onderbreek deur weerligstrale en 'n maalkolk van krisis en verlies aan beheer. 'n Deurwerk van die maalkolk-periode en eksternalisering van die probleem kan "dor plekke" voed en weer 'n nuwe "fontein" laat ontspring (vgl. Jes. 58:11).

Indien die pastorale versorger so 'n metafoor as 'n brug gebruik om eksternalisering te laat plaasvind, kan verwerking plaasvind. Die verdere koppeling van die siekte aan die "dor plekke" in die pasiënt se geloofsmondering en die "versterking" daarvan soos wat Bettie en Faan dit self gesien het, bring geloofsgroei na vore wat lei na die ontspringing in 'n "fontein" van hantering.

\section{Kennisvaardigheid: samevattend}

- In die oordrag van die diagnose is dit belangrik dat die pasiënt gevra moet word watter inligting hy/sy wil hoor en wat nie.

- Die eerste groepering van vaardighede is die kennisvaardigheid.

- Persoonlikheidsverskille ten opsigte van die verkryging van inligting moet gerespekteer word.

- Pasiënte reageer nie eenders op inligting nie - sommiges gebruik inligting tot verwerking en vir ander is 'n dag-vir-dag hantering belangriker.

- Kennis kan 'n kanaal bied vir aanvaarding, asook vir realistiese hoop.

- Eksternalisering van die probleem lei tot objektivering en 'n beter hantering van die gevolge van die probleem.

- Vaardighede kan makliker geïdentifiseer word wanneer die metafoor en eksternalisering aangewend word.

- 'n Metafoor is 'n handige brug om vanaf die maalkolk te kom tot by die verstaan van die "dor plekke" wat gevoed moet word.

Hierdie eerste groep hanteringsvaardighede verwys alreeds inherent na verhoudings. Die volgende tema handel oor verhoudings as 'n hanteringsvaardigheid.

\section{Verhoudingsvaardigheid}

En jy sal wees soos ' $n$ tuin wat goed besproei is (vgl. Jes. 58:11).

Die verhoudingsvaardigheid verwys na die opbou en instandhou van positiewe verhoudings. Die pasiënt vertel sy/haar verhaal oor 
verhoudings van die verlede en gaan dan oor na die hede, waarin nuwe verhoudings (dokters, verpleegsters, vrywilligers, medekankerlyers) na vore kom. Ook 'n nuwe verhouding met God ontstaan uit die opstand en stryd van die maalkolk. Die ontwikkeling van die alternatiewe storie, maak voorsiening vir 'n (terug)binding aan God en die verhoudings van die verlede en hede word versterkend in die lewenstuin opgeneem.

Müller (1996:99 en 104) wys in sy "pastoraat van narratiewe betrokkenheid" op die verband tussen verhoudings van die verlede en die ontwikkeling van 'n nuwe (alternatiewe) storie. Die proses word geblokkeer deur 'n verhaal van nood, naamlik die diagnose en siekte wat die maalkolk veroorsaak. Die hergestruktureerde verledeverhaal en die verduisterde toekomsverhaal ontspring in 'n nuwe, alternatiewe verhaal. Müller verduidelik tydens 'n werkswinkel die begrip "alternatiewe storie" as "To create a different reality or a new possibility. To STOP and see your story in another way. Therefore, finding a way of being the person I am!" (Müller \& Human, 2004).

Lizelle, 'n 22-jarige meisie, se maligne karsinoom het reeds versprei na die rugmurg toe ek haar ontmoet het. Vir drie weke kon sy nie self opstaan, loop of normaal funksioneer nie. Sy was totaal afhanklik van haar vriend en sy gesin om haar oral heen te neem. $\mathrm{Na}$ ' $\mathrm{n}$ operasie het sy vir die laaste twee maande van haar lewe weer die gebruik van haar bene en rug teruggekry. Twee verhoudings, wat die diepste donkerte van haar maalkolk oorleef het, het vir haar voorop gestaan:

Hoe kan enige jong man sy lewe weggooi om na my te kyk? Ek kan dit nou nog nie verstaan nie! Maar ek weet, net soos wat Jesus vir my lief is, so lief is Jannie vir my.

Lizelle en haar ouers is na die maalkolk-periode versoen. Skuldgevoelens oor haar siekte het hulle aanvanklik uitmekaar gehou. 'n Erkenning van God se genadige vrede en verlossing het nie net 'n terugkeer bewerkstellig nie, maar ook weer menslike verhoudings in liefde herstel.

Warren (2002:255) bevestig bogenoemde gebeurtenis deur te stel dat "stories wat gedeel word, 'n verhoudingsbrug bou waaroor Jesus van jou hart na ' $n$ ander se hart kan loop". Bucer, soos aangehaal deur Pretorius (2003:171), bevestig dit as ook hy verklaar: 
De mystieke unie met Christus berust op het werk van de Geest, die ons in Christus inkorporeert, inlijft, inzaait, inent, ons tot één plant met Christus doet worden ...

Bettie en haar man het tydens die leënessindroom so ver uitmekaar gedryf, dat daar reeds sprake was van 'n egskeiding. Nadat daar vasgestel is dat die maligne melanoom reeds versprei het, het hul lewenspaaie weer inmekaar begin vloei. Op die vraag "watter verhouding is vir jou nou die belangrikste?", het Bettie geantwoord:

Ek dank die Here dat ons lewenspaadjies nie uitmekaar is nie.

Ek weet nie wat ek sonder my man in hierdie tyd sou gedoen het nie. Daar is nog verhoudings wat vir my belangrik is, die nuwe vriende wat ek verkry het deur ons groep by KANSA. Nuwe lede kom by, die oues val uit en afwesighede kom weekliks voor, maar net om te weet dat iemand anders dieselfde probleme as jyself ervaar en dus 'n oor en 'n hart het wat verstaan, maak die lyding draagliker.

Katinka is stomgeslaan oor die ondersteuning van haar gesin. Sy weet ook dat juis haar gesin se ondersteuning haar beste hanteringsvaardigheid is. Nadat sy gediagnoseer is met 'n kankermelanoom 'n jaar gelede, het dinge vinnig gebeur. Sy het haar duim verloor en kort daarna is ' $n$ klier onder haar arm weggesny. Nadat die duim verwyder is, het die dokter gesê dat die volgende gewoonlik die elmboog is. Sy spot so ewe en vra: "Hoe sal ek sonder 'n elmboog lyk?" Sy en haar gesin lag saam, huil saam en offer saam hul vakansie op sodat sy kan terugkom vir haar behandeling. Op 'n dag toe sy huil oor die feit dat die behandeling haar so siek maak, wou haar man haar keer dat sy nie voor die kinders moet huil nie. Haar seun het onmiddellik na vore gekom met:

$\mathrm{Pa}$, los vir Ma dat sy huil as sy wil. Dit sal dit vir haar beter maak. Ek en Sus is mos saam met julle in hierdie ding! Ons is okay daarmee!

$\mathrm{Na}$ 'n vraag aan haar dogter in graad tien hoe sy haar ma se siekte hanteer, antwoord sy:

Het jy al die seep-advertensie met die groot seepbel gesien? Ons gesin is in daardie seepbel. En daardie buiterand van die seepbel?, dit is Jesus wat ons vashou in die seepbel - dis hoekom ek nie bang is nie. 
Gerkin (1991:91) se uitspraak versterk die belangrikheid van die metafoor van die teenwoordigheid van God in ons lewens - veral in donker tye:

The theme of presence is traced as an organizing metaphor across the long sweep of Biblical history. The significance of the metaphor of presence is primary in Biblical religion ...

Bettie, Katinka en Lizelle se verhaalstudies bevestig die versterkende invloed wat gesinsverhoudings bied. Nie net kan hulle saamstaan wanneer die maalkolk dreig om almal te verswelg nie, maar hulle kan mekaar ook ondersteun wanneer die siekte een van hulle deur die donkerste diepte meesleur. So 'n saamstaan is soos die lushof van 'n "tuin wat goed besproei is" (Jes. 59:11) - 'n tuin waarin almal wil vertoef om die rustigheid en vrede van God se teenwoordigheid te ervaar. Hier kan die Tuinier se liefde ervaar word en kan groei plaasvind, sodat "lote vrugte dra" (Joh. 15:2).

\section{Verhoudingsvaardigheid: samevattend}

- Geen mens kan sonder die ondersteuning van ander mense 'n siekte soos kanker verwerk, aanvaar en begin om 'n nuwe, alternatiewe verhaal te skryf nie. Die uittrek uit die maalkolk van verswelging na ' $n$ tuin wat ' $n$ lushof is, kan net gebeur wanneer vriende en geliefdes mekaar ondersteun.

- Die verloop van die siekte raak die naaste persone soms meer as die kankerpasiënt self. Humor asook metafore gee aan gesinslede eksternaliseringsmoontlikhede wat die hantering kan verbeter.

- Verledeverhoudings en nuwe verhoudings lei tot versterking van die hantering van die siekte.

- Ondersteuningsgroepe bring ook positiewe hantering na vore.

- Stories wat gedeel word, bou 'n verhoudingsbrug van een hart na ' $n$ ander en die samebinding kan in Jesus Christus wees.

- Die belewing van die teenwoordigheid van God in die lewe van die mens, veral in "dor" tye, is 'n primêre metafoor van die Bybelse narratief (groot narratief van God).

Daar is alreeds in hierdie gedeelte geraak aan die ontwikkelingshanteringsvaardigheid. Vervolgens sal breedvoeriger daaraan aandag gegee word. 


\section{Ontwikkelingsvaardigheid}

... en jy sal wees ... soos 'n fontein van waters waarvan die water nooit teleurstel nie (Jes. 58:11).

Dié ontwikkelingsvaardigheid is gekoppel aan die identifisering van unieke uitkomstes. White en Epston (1990:55) beskryf 'n unieke uitkoms as 'n fasiliteerder van nuwe betekenisse - die goue oomblikke in enige storie wat die alternatiewe storie laat ontspring. Dit spreek vanself dat hierdie goue oomblikke nie net in die hede kan ontspring nie, maar ook uit die verlede en in die teenswoordige kan ontspring in 'n "nuwe" fontein. Verder bied unieke uitkomstes ook verbandsmoontlikhede met die Groot Narratief van God.

Clinebell (1984:112) stel dit dat ontwikkeling volgens die Bybel 'n geskenk is wat intensionele stryd en pyn veronderstel voordat die "ou mens" afsterf en die "nuwe mens" geleidelik te voorskyn tree (Matt. 7:14; Joh. 3:3 en Rom. 6:6). Petrus noem (1 Pet. 1:6) dat hierdie ontwikkeling wat uit beproewing voortvloei, 'n vreugde behoort te wees. Venter (2003:32) verduidelik dat volgens Hebreërs 12:3 die pastorale versorger, as verteenwoordiger van Christus, in ' $n$ "intieme verhouding" met die pasiënt hoop kan bedien.

Bogenoemde uitsprake trek Jesaja $58: 11$ se metafoor saam, naamlik: die dor plekke wat gevul word en sterk gemaak word (tydens die maalkolk-periode), die tuin (van rus) wat goed "ondersteun" word deur sterk verhoudings en dan laastens die fontein waar waters wat "nou" nooit teleurstel nie. Laasgenoemde dui op ontwikkeling.

Die waarde-ontwikkeling as deel van die ontwikkelingsvaardigheid, verwys na die herontdekking van "my waarde in Christus", as deel van die unieke uitkoms en ontspringing van 'n nuwe lewenstroom. Browning (1991:206) verwys hierna soos volg:

The Christian narrative of the cross adds an obligation to go the second mile in the communicative situation ... The Christian narrative contributes to freer and less distorted communication as well as revitalization and renewal.

Ria het haar man se maligne karsinoom moeilik verwerk. Dit was asof die maalkolk van onbeantwoorde vrae haar weer en weer meesleur, veral as sy moes wag vir die afhandeling van die weeklikse chemo-behandeling. Met die saamstel van hulle lewensverhaal het sy verwys na die waarde van gebed as lewenshanteringsvaardigheid in haar lewe. Elke gebed van haar het 
die Gees beantwoord, al was dit om te wys dat haar versoek/behoefte nie toegestaan kan word nie.

Op 'n vraag aan haar of sy al nuwe vriende gemaak het met van die mense wat ook sit en wag by die chemo-behandeling, het die goue oomblik vir haar deurgebreek:

Ek het nog nooit daaraan gedink nie! Ek kan soveel beteken vir die mense wat ook sit en wag, al is dit net om te gesels. Verder kan ek vir hulle bid ook - veral as ek weet wat hulle omstandighede is!

Wanda is vir ' $n$ tweede keer gediagnoseer met kanker. Hierdie keer was die maalstroom baie erger as die eerste keer. Sy het dan so hard gebid dat die Here haar sal genees. Verskeie vrae het haar geteister. Toe sy op 'n stadium in die wagkamer sit, bring 'n klein kaalkop dogtertjie die son in die morbiede kamer in. Wanda het net daar begin huil toe sy hoor dat die dokters niks meer vir die kind kan doen nie. Haar huil skakel om in 'n gebed en die Here wys toe aan haar elkeen in haar gesin en ook haar ouers - sou sy graag wou hê een van hulle moet haar siekte oorneem? Sy besef vir die eerste keer dat die Here selfs met haar siekte ' $n$ doel het - Hy is besig om haar in "dor plekke" te versadig, "haar te maak soos 'n fontein ...". Vir die eerste keer het sy vrede gevind en dit reggekry om haar verhaal in 'n alternatiewe storie te omskryf.

'n Pasiënt worstel dikwels met die probleem dat die siekte hom/haar totaal en al beheer laat verloor. ' $n$ Vrywilliger van KANSA het tydens 'n werkswinkel vertel:

Om beheer van jou hele wêreld te verloor, is veral by die manlike kankerpasiënt baie moeilik. Sy hele lewe deur is hy die finansiële voorsiener, beskermer en hoof van sy huis. Nou moet hy beheer opgee en/of oordra aan iemand anders.

Verlies aan beheer bring die maalkolk-periode na vore. Skielik moet 'n pasiënt sy beheerbare wêreld verlaat om in 'n "siekte-wêreld" aan te pas of te verander. Die Griekse woord metanoia (metamorfose) is hier van toepassing. Christus wil dat ons ons lewens verander en in sy hande oorgee - Hy sal voorsien in alle omstandighede (Ps. 91:4; Heb. 13:5; 2 Tim. 1:7; Filip. 4:19).

Jenny, 'n vrywilliger, verwoord die intense worsteling van 'n mens met God, terwyl sy langs 'n ma gesit het wat haar kind na 'n lang lyding, aan die dood moes afstaan (Buxton 2004:187): 
Jenny believed that, on the one hand, she ought as a Christian to be defending God's ultimate good purposes for all. On the other hand, she felt bound to be alongside this grieving person almost against God ...

Hierdie gebeure bring "onoplosbare" vrae (vergelyk die inleiding) wat sekerlik in so 'n situasie in elke mens sal maal. 'n Terugbind aan God se Narratief, naamlik dat elke mens gelowig soos 'n kind moet bly vashou aan God se beloftes, kan 'n alternatiewe storielyn na vore bring.

Vir Jenny het die oplossing gekom toe sy God se doel met elke persoon vergelyk het met ' $n$ komponis wat in opdrag 'n werk moes komponeer. Op die dag van die uitvoering sit jy in vervoering en luister na die wonder van musiek en die meesterlike afronding en perfekte passing van elke musiekinstrument. Sou jy egter die studeerkamer van die komponis besoek het 'n jaar of twee jaar voor die aangewese dag, sou jy 'n deurmekaar worsteling van musiekstukke en ook 'n duistere ongekoördineerde sameflans van oefenstukke gesien en gehoor het. Dit, verklaar Jenny, is hoe God ook met ons besig is. Ons taak is net om gelowig vas te hou aan die feit dat Hy besig is om van ons 'n meesterstuk te maak.

Die alternatiewe storie bring 'n nuwe waarde-ontwikkeling, 'n nuwe belangstelling (unieke uitkoms) en in baie gevalle ook 'n weg om dienskneg te wees soos God dit vir ons bedoel het (Warren 2002:215). Karen getuig byvoorbeeld na haar ma se dood:

Sy het 'n lyding gehad wat sy net self kon beskryf, maar ek het haar nog nooit, in haar hele lewe, so gelukkig gesien nie. Sy het vroeër altyd gebid dat die Here haar 'n kans moet gee om vir Hom te getuig, en dit het haar stokperdjie geword terwyl sy in die bed gelê het. Aan die honderde mense wat haar kom besoek het, het sy getuig. Haar getuienis het gegaan oor die verlossingsverhaal van Jesus Christus in haar lewe.

Om 'n alternatiewe storie uit die maalkolk-situasie te laat ontspring, bring nuwe hoop en 'n metamorfose in 'n pasiënt se lewe. As daar dan teruggeblaai word na die "vorige lewe", word die soeke na identiteit in Christus, elke besonderheid en ervaring van die lewe, 'n nuwe fontein.

\section{Ontwikkelingsvaardigheid: samevattend}

- 'n Unieke uitkoms fasiliteer nuwe betekenisse wat 'n alternatiewe verhaal moontlik maak. 
- Ontwikkeling gaan gepaard met 'n pynlike metamorfose - in hierdie geval, die lyding van kanker.

- Dié pynlike metamorfose maak die lydendes vry om mense te wees soos God dit bedoel het.

- Die maalkolk dreig om ook die hospitaalbedienaar en pastorale versorger te verwar.

- 'n Nuwe waarde-ontwikkeling laat 'n fontein uit die maalkolk ontspring wat groei tot nuwe belangstelling en die uitreik na ander - soos 'n dienskneg van Jesus Christus.

- Slegs in Christus kan die fontein "water word wat nooit teleurstel nie".

Die laaste groepering van hanteringsvaardighede gaan juis oor die ontwikkeling van 'n nuwe lewenstroom, 'n alternatiewe storie en die verbinding daarvan met jou ware identiteit (roeping) in Christus. As diensknegte behoort ons uit te reik, te gee, as pasiënt of vrywilliger, as pastorale versorger of as hospitaalbedienaar. Deur ander te begelei, word die suiwerende lewenstroom in die eie lewe ervaar, en God se belofte gaan in vervulling: "... water, wat nooit teleurstel nie (Jes. 58:11).

\section{Samevatting}

In hierdie artikel is die lewenshanteringsvaardighede in groeperings geïdentifiseer en elkeen aan die hand van gedeeltes van verhalestudies van kankerpasiënte verduidelik. Nuwe fonteine van doelgerigte lewens het ontspring uit pasiënte se alternatiewe stories en telkens is dié stories gevul met God se bedoeling van sy verhaal.

Die betekenis van hierdie artikel vir pastorale versorgers en hospitaalbedienaars is die identifisering en ontwikkeling van lewenshanteringsvaardighede uit elke persoon se geskiedenis, juis omdat elkeen in die hand van die Pottebakker gevorm word.

Die kennisvaardigheid sluit eksternalisering, metafore, aanvaarding en hoop in. Deur die verhoudingsvaardigheid kan verledeverhoudings en nuwe verhoudings saam versterking of ondersteuning meebring. Geloofsgroei en die dienende ontwikkelingsvaardigheid is unieke uitkomste. Dit bring nuwe belangstellings na vore en 'n nuwe waarde in Christus, wat dui op 'n (terug)binding aan die groot narratief van die Bybel.

Die uitdaging van die pastorale versorger, as instrument van die Heilige Gees, is die metaforiese oorbrugging vanaf die opslurping in 
die donker dieptes van 'n maalkolk na 'n gevoel van verfrissing deur die lewende water van Jesus Christus.

\section{Geraadpleegde bronne}

ANDERSON, H. \& GOOLISHIAN, H. 1992. The client is the expert: a notknowing approach to therapy. (In McNamee, S. \& Gergen K.J., eds. Therapy as social construction. London: Sage. p. 25-39.)

BOTHA, S. 2003. Gèsed-kursus. Bloemfontein: NG Kerk Langenhovenpark.

BROWNING, D.S. 1991. A fundamental practical theology. Minneapolis: Fortress.

BUXTON, F. 2004. Flawed God? Christian and Muslim theodicies in the hospital setting. (In Foskett, J. \& Lartey, E., eds. Spirituality and culture in pastoral care and counselling: voices from different context. Cardiff: Cardiff Academic Press. p. 181-189.)

CLINEBELL, H. 1984. Basic types of pastoral care and counseling. Nashville: Abingdon.

GERKIN, C.V. 1997. An introduction to pastoral care. Nashville: Abingdon.

JANSE VAN RENSBURG, J. 1996. Verbond en pastoraat. Nederduitse Gereformeerde Teologiese Tydskrif, 37(1):152-165.

KÜBLER-ROSS, E. 1975. On death and dying. New York: Touchstone.

LEFAVI, R.G. \& WESSELS M.H. 2003. Life review in pastoral counseling: background and efficacy for use with the terminally ill. The Journal of Pastoral Care \& Counseling, 57(3):281-292.

LESTER, A.D. 1995. Hope in pastoral care and counseling. Kentucky: John Knox.

LOUW, D.J. 1982. Pastoraat en lyding: enkele teologiese kernbegrippe met betrekking tot die lydingsvraagstuk as pastorale probleem. Kaapstad: NG Kerkuitgewers.

MÜLLER, J.C. 1996. Pastorale gesinsterapie: om tot verhaal te kom. Pretoria: RGN-uitgewers.

MÜLLER, J.C. \& HUMAN, L. 2004. Imaginative pastoral counselling. Workshop presented on 16-17 August. Bloemfontein: UFS.

POWELL, H. 2004. Care for a terminally ill person: a guide for pastors. In die Skriflig, 38(2):351-375.

PRETORIUS, J. 2003. Die groot fokus, die groot gebod en die groot opdrag as sleutels in 'n model van gemeentebou. Potchefstroom: $\mathrm{PU}$ vir $\mathrm{CHO}$. (Ph.D.- proefskrif.)

STEYN, J. 2001-2005. Uit my hospitaaldagboek: versameling van verhalestudies. Transkripsie in besit van die outeur.

STEYN, J. 2004. Die ontwikkeling van 'n model in pastorale terapie. Bloemfontein: UVS. (Ongepubliseerde Honneurs skripsie in Praktiese Teologie.)

STRYDOM, H. 2002. Participatory Action Research. (In De Vos, A.S., ed. Research at grass roots: For the Social Sciences and Human Service Professions. Pretoria: Van Schaik. p. 419-434.)

VAN DEN BERG, J.-A. 1998. Metaforiese pastorale gesinsterapie. Pretoria: UP. (Ph.D.-proefskrif.)

VAN JAARSVELD, F.J. 2001. Die rol van Gods-konsepte vir pastorale terapie: 'n konstruk teoretiese benadering. Bloemfontein: UVS. (Ongepubliseerde Ph.D. in Praktiese Teologie.) 
VENTER, C.J.H. 2003. Die prediking van hoop aan getraumatiseerdes in die huisgesin van God: prakties-teologiese perspektiewe in die lig van Hebreërs. In die Skriflig, 37(1):27-50.

WARREN, R. 2002. A purpose-driven life. Grand Rapids: Zondervan.

WHITE, M. 2004. Working with people who are suffering the consequences of multiple trauma: a narrative perspective. The International Journal of Narrative Therapy and Community Work, 1:45-76. www.dulwichcentre. com.au Date of access: 27 Jun. 2004.

WHITE, M. \& EPSTON, D. 1990. Narrative means to therapeutic ends. New York: Norton.

WYLIE, M.S. 1994. Panning for gold. The Family Therapy Networker: 40-48, Nov./Dec.

YANCEY, P. 2001. Where is God when it hurts? Grand Rapids: Zondervan.

\section{Kernbegrippe:}

groot narratief

hanteringsvaardighede

pastoraal-narratief

versorger

Key concepts:

caregiver

coping skills

great narrative

pastoral-narrative 
